$1-1-1991$

\title{
The Death Penalty and Gender Discrimination
}

Elizabeth Rapaport

University of New Mexico - School of Law

Follow this and additional works at: https://digitalrepository.unm.edu/law_facultyscholarship

Part of the Law and Gender Commons

\section{Recommended Citation}

Elizabeth Rapaport, The Death Penalty and Gender Discrimination, 25 Law \& Society Review 367 (1991).

Available at: https://digitalrepository.unm.edu/law_facultyscholarship/134

This Article is brought to you for free and open access by the UNM School of Law at UNM Digital Repository. It has been accepted for inclusion in Faculty Scholarship by an authorized administrator of UNM Digital Repository. For more information, please contact amywinter@unm.edu, Isloane@salud.unm.edu, sarahrk@unm.edu.

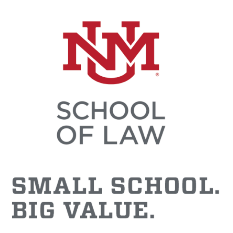

BIG VALUE. 
Volume 25 No. 21991
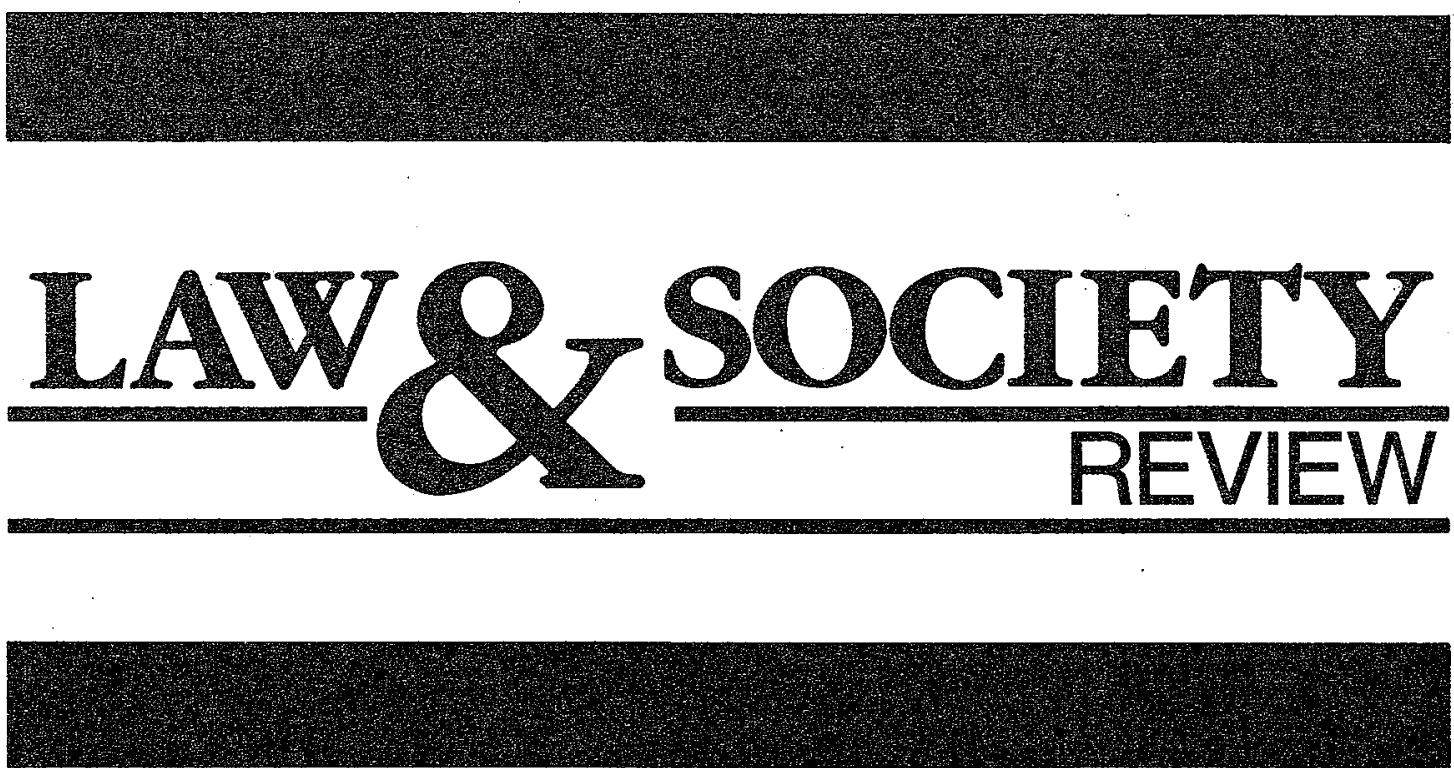

\section{The Journal of the Law and Society Association}

\section{Special Issue on Gender and Sociolegal Studies}

\section{INTRODUCTION}

Carrie Menkel-Meadow \& Shari Seidman Diamond

ARTICLES

John Hagan, Marjorie Zatz, Bruce Arnold, \& Fiona Kay Jane Goodman, Elizabeth F. Loftus, Marian Miller, \& Edith Greene

Rosemary Gartner \& Bill McCarthy

David A. Ford

Susan L. Miller \& Sally S. Simpson

Elizabeth Rapaport Adelaide $H$. Villmoare

REVIEW ESSAYS

Lynne Henderson

Gayle Binion
The Content, Method, and Epistemology of Gender in Sociolegal Studies

Cultural Capital, Gender, and the Structural

Transformation of Legal Practice

Money, Sex, and Death: Gender Bias in

Wrongful Death Damage Awards

The Social Distribution of Femicide in Urban Canada, 1921-1988

Prosecution as a Victim Power Resource: A Note on Empowering Women in Violent Conjugal Relationships

Courtship Violence and Social Control: Does Gender Matter?

The Death Penalty and Gender Discrimination Women, Differences, and Rights as Practices: An Interpretive Essay and a Proposal

\section{Law's Patriarchy}

- On Women, Marriage, Family, and the Traditions of Political Thought 


\title{
THE DEATH PENALTY AND GENDER DISCRIMINATION
}

\author{
ELIZABETH RAPAPORT
}

\begin{abstract}
Despite the paucity of research on the death penalty and gender discrimination, it is widely supposed that women murderers are chivalrously spared the death sentence. This supposition is fueled by the relatively small number of women who are condemned. This article argues that women are represented on contemporary U.S. death rows in numbers commensurate with the infrequency of female commission of those crimes which our society labels sufficiently reprehensible to merit capital punishment. Additionally, preliminary investigation suggests that death-sentenced women are more likely than death-sentenced men to have killed intimates, although the explanation for this disparity is not yet at hand. It is further argued, on the basis of a content analysis of state capital statutes, that there is a form of gender bias inimical to the interests of women in our capital punishment law: The death penalty is a dramatic symbol of the imputation of greater seriousness to economic and other predatory murder as compared with domestic murder.
\end{abstract}

It would seem, superficially at least, that if there is gender discrimination in the U.S. capital punishment regime, it favors female offenders. At most 2 percent of those executed from colonial times to the present have been female (Bedau 1982:3). In the modern death penalty era, which begins with the Supreme Court's constitutional invalidation of then existing capital statutory schemes in 1972 and the imposition of novel constitutional requirements on the fashioning of such statutes in 1976, approximately 2 percent of those condemned have been female. ${ }^{1}$ Only one woman has been among the 143 persons executed since executions resumed in 1977, after a decade-long moratorium during which the future of capital punishment in the United States had been in doubt (NAACP Legal Defense and Educational Fund 1991:1). A gross comparison of the death-sentencing rates for men and women suggests that women convicted of murder are underrepresented on death row. Two per-

I would like to thank David Baldus, Philip Cook, and Alex Keyssar for helpful conversations about gender and the death penalty, and Shari Diamond for invaluable assistance in the preparation of this article. I would also like to thank Charles Dainoff and Anna Tefft for research assistance.

1 See Strieb (1991:2), who makes an informed estimate based on review and collation of the sources of information available. See also Strieb 1990.

LAW \& SOCIETY REVIEW, Volume 25, Number 2 (1991) 
cent of men but only one tenth of 1 percent of women convicted of murder are condemned to die. ${ }^{2}$

For a feminist to raise the issue of gender discrimination and capital punishment is not an altogether comfortable undertaking. At worst, it suggests a campaign to exterminate a few more wretched sisters. In my view, however, the issue is worth confronting. The reputed leniency that women receive with respect to death sentencing supports the view widely held in our society that women are incapable of achieving, nor are they in fact held to, the same standards of personal responsibility as are men. Although there may well be fields of endeavor in which the most profound forms of equality call for recognition of difference, equal democratic citizenship can proceed from no other premise than that of equal personal responsibility for decisions and actions. ${ }^{3}$ The chivalry from which women supposedly benefit is too costly: In ideological coin it is supposed to be repaid with tacit recognition of the moral inferiority of females and our lack of aptitude for full citizenship. As a matter of both logic and political necessity, then, feminists must embrace either gender-neutral evenhandedness or abolitionism.

There has been very little research on the death penalty and gender discrimination, either before or after the Supreme Court mandated a new constitutional regime for the administration of capital punishment in 1976; yet the charge that women receive favorable treatment has been aired, notably by Justice Marshall in his concurring opinion in Furman v. Georgia (1972), in which he asks, rhetorically, how the disparity between the number of murders women commit and the number of women executed can be explained other than by discrimination in favor of women (ibid., $p$. 365). ${ }^{4}$

2 U.S. Bureau of Justice Statistics (1990:9), reporting findings of a survey of state prison inmates in $\mathbf{1 9 8 6 .}$

3 There has been considerable debate among feminist legal theorists as to whether wormen ought to seek formal equality with men or to urge what is often called special treatment, i.e., legal rights recognizing pertinent gender differences, such as employee leave for pregnant women. The position I take on gender and the death penalty resembles the position taken by Williams $(1982)$ : in that I maintain that acceptance of special treatment would be purchased at the price of leaving damaging stereotyping practices intact. I agree with Williams on issues that implicate women's status as full-fledged citizens, with the moral and political capacities thereof, e.g., laws protecting minor females but not minor males under statutory rape laws, or the blanket female exemption from the military draft; but the recognition of biological and socialfunctional realities supports, I think, a different treatment stand on some issues. See Littleton 1987 and Minow 1987. If gender-neutral equality is the goal of criminal law reform, this ought not to be misconstrued to mean endorsing legal regimes that promote a spurious equality at the expense of genuine gender neutrality. E.g., the law of self-defense, which typically imposes on female defendants some requirements that can only reasonably be expected of males, is not gender neutral (see Gillespie 1989). Nor, as I argue in part III below, is the law of capital punishment gender neutral as it currently exists.

4 Sellin (1980:66-68) concluded that women received favorable treatment 
Does the sparseness of women on death row result from a chivalrous disinclination to mete out death to women under circumstances in which men would be consigned to this fate? Or does the apparent underrepresentation of women have an explanation other than gender discrimination in our favor? Two hypotheses, singly or in combination, would account for the gender profile of America's death rows: (1) women offenders are benefiting from gender discrimination in their favor; (2) women are represented on death row in numbers commensurate with the infrequency of female commission of those crimes our society labels sufficiently reprehensible to merit capital punishment.

In the first part of this article I explore what currently available information can tell us about the extent of gender discrimination in selection for death. I then offer a profile of condemned men and women in order to compare the crimes and the characteristics of male and female capital offenders. The question explored there is whether men and women are selected for the most severe sanction our society can impose for the same or different sorts of reasons. In the final part I discuss a form of gender discrimination built into U.S. death penalty law that expresses and reinforces the subordination of women: Under modern era law, the death penalty is a possible punishment only for crimes and criminals that evoke our society's most extreme condemnation. The crimes whose prohibition we solemnize by treating as death eligible are those which, overwhelmingly, are predatory crimes committed by men against other men or against women and children not their own. The death penalty, therefore, is a dramatic symbol of the lesser dignity attached to the security and peace of the domestic sphere as compared with the realms of commerce and intercourse among nonintimates.

\section{CHARACTERISTICS OF MALE AND FEMALE MURDERERS AND OF OFFENDERS SELECTED FOR DEATH}

According to FBI Supplementary Homicide Reports (SHR) data, in the twelve years $1976-87$, women made up 14.3 percent of murder and nonnegligent manslaughter suspects known to the po-

in his study of the pre-Furman death penalty system. However, two researchers who to determine whether racial bias was present studied the post-Furman system found no evidence of gender bias in the cases they examined. In a study of 604 defendants arrested for homicide in North Carolina 1977-78, 18.7 percent of whom were women, Nakell and Hardy (1987:93, 139-40) found no significant differences between the sexes in the likelihood of being tried or sentenced for first-degree murder or of receiving a life or death sentence. Baldus, Woodworth, and Pulaski (1985:1385; 1990:494) found that gender did not have a statistically significant impact on sentencing outcomes in their study of the operation of the death penalty in Georgia 1979-81, although they do report a weak correlation between being a female defendant and a nondeath penalty sentencing outcome. They studied 607 cases of persons convicted of murder, 10 percent of whom were women. These results must be received with caution because the number of women in each study was small. 
lice..$^{5}$ If women commit 14 percent of all such killings, they commit substantially fewer of those murders that are subjected to capital adjudication. The great majority of capital sentences are meted out to those who have committed felony murder, murder committed during the course of another serious felony, and other predatory murders. More than 80 percent of the death sentences in some jurisdictions that have been studied are pronounced on felony murderers; nationally the percentage exceeds 75 percent. ${ }^{6}$ Women seldom commit felony murders. Of 20,905 persons suspected by the police of the felony murders of rape, burglary, robbery, auto theft, arson, and the catch-all category of other felony for 1976-87, only 6.2 percent were women. ${ }^{7}$ Table 1 reveals the suspected involvement of women in the categories of murder most likely to yield a death sentence. ${ }^{8}$ of particular interest is robbery murder: 67.4 percent of the 20,905 felony murders for 1976-87 were robbery murders.

Most murders, whether committed by men or women, are not sufficiently aggravated to tempt prosecutors to pursue a death penalty. ${ }^{9}$ An important reason why so few women are eligible for capital sentences is that women who kill are more likely than men to kill family and other intimates in anger rather than to kill for a predatory purpose. Predatory murder is committed to gain some material or other advantage, in contrast with killing that appears to be stimulated by powerful emotion. Felony and other predatory murders are most often committed against strangers and least often committed against family and other intimates. The victims of

5 Supplementary Homicide Reports (SHR) are compiled by the FBI's Uniform Crime Reporting (URC) section from information filed by local law enforcement agencies. I would like to thank James Alan Fox of the National Crime Analysis Program at Northeastern University for supplying me with the FBI SHR data on which the murder statistics in this article are based. SHR statistics reflect both murder and nonnegligent manslaughter, defined by the FBI URC as "willful nonnegligent killing." In my discussion of the import of SHR data, I use the term "murder" expansively to include all willful nonnegligent killing, including nonnegligent manslaughter.

6 Gross and Mauro (1989:45) found that in 1976-80 over 80 percent of the death penalties in Florida and Georgia were in felony murder cases, as were 75 percent in Illinois. Ekland-Olson (1988:859) reports that in 1974-83 in Texas, 72 percent of death sentences involved cases of robbery, burglary, or sexual assault. According to the NAACP Legal Defense and Educational Fund, which monitors America's death rows, in 1986 more than 75 percent of death row cases involved felony murder. See Baldus, Pulaski, and Woodworth 1986:139.

7 These SHR data, it must be said, are relevant to the inquiry only if police suspicions reflect the underlying distribution of murders by men and women.

8 Gross and Mauro (1989:45-50) found that commission of murder during the course of another felony, stranger victim, and multiple victims were the three factors most likely to lead to a death sentence.

9 Nakell and Hardy (1987:136), e.g., report that in a year period in 1977-78 in the middle-sized death penalty state of North Carolina, in most judicial districts between 5 and 15 percent of all homicide cases went to trial as first-degree murder cases, thus having the potential for capital sentencing. 
Table 1. Categories of Murder Most Likely to Receive the Death Sentence, Male and Female Suspects, 1976-1987

\begin{tabular}{lrrrr}
\hline & & \multicolumn{3}{c}{$\%$ Committed by } \\
\cline { 3 - 4 } & No. & Males & Females \\
\hline Felony murder & 20,905 & 93.8 & 6.2 \\
Robbery murder & 14,093 & 96.0 & 4.0 \\
Rape murder & 1,505 & 96.1 & 3.9 \\
Stranger murder & 31,506 & 96.1 & 3.9 \\
Multiple viction murder & 5,218 & 92.8 & 7.2 \\
All murders & 172,961 & 85.7 & 14.3 \\
\hline
\end{tabular}

SoURCE: FBI SHR data. See note 5.

NOTE: In 25.8 percent of the cases the gender of the suspect was unknown.

Table 2. Distribution of Murder Victims by Relationship to Female and Male Murder Suspects, 1976-1987

\begin{tabular}{lcc}
\hline & Female & $\begin{array}{c}\text { Male } \\
\text { Suspect }\end{array}$ \\
Relationship of Victim to Suspect & Suspect & $22.1 \%$ \\
\hline Intimate: & 48.9 & 11.8 \\
Spouse, lover, and ex & 10.4 & 2.7 \\
Child & 6.2 & 7.6 \\
Other family & 26.9 & 47.1 \\
Acquaintance, friend, and other known & 5.0 & 20.4 \\
Stranger & 3.3 & 10.2 \\
Unknown & $100.0 \%$ & $99.8 \%$ \\
& 24,786 & 148,175 \\
No. of victims & &
\end{tabular}

SOURCE: FBI SHR data. See note 5.

NotE: Rows are defined as follows: Spouse, lover, and ex-husband/wife, common-law husband/wife, ex-husband/wife, boyfriend/girlfriend, homosexual relationship; child-both adult and minor children, includes stepchild; other familyparent, sibling, in-law, other family; acquaintance, friend, and other knownfriend, acquaintance, neighbor, employer, employee, and other known to victim; stranger-not known to victim.

women killers are substantially more likely than those of men to be family members and less likely to be strangers (Table 2).

If men and women received evenhanded treatment, and no factor other than the broad category of the offense was causally related to sentencing outcomes, we would expect the percentage of women on death row to be about 4 percent-reflecting female participation in the most heavily sanctioned felony murders, robbery, and rape murders-or perhaps as high as 6 percent-reflecting female participation in felony murder of all kinds (see Table 1). We would certainly not expect the proportion of death-sentenced women to be 14 percent, to reflect the extent of female participation in murders of any and every kind. That other factors in addition to broad offense categories affect sentencing outcomes further decreases the proportion of women one would expect to find among the condemned.

The great majority of felony murderers and other categories 
of prime death-eligible murderers are not death sentenced. At least three additional factors legitimately influence which felony murderers and other potential capital defendants are subject to capital trials and death sentences. The "legitimacy" I speak of here is that conferred by legislative enactment and the sentencing policies embodied therein. Some aspects of these policies will be treated critically in part III. My concern here is limited to assessing the impact of current statutory sentencing schemes on the gender composition of U.S. death rows. Three factors that legitimately influence selection for death, then, are prior criminal record, offense seriousness, and degree of culpability. ${ }^{10}$ There are indications that at least two of these factors, prior record and offense seriousness, legitimately expose more male than female murderers to capital sentencing.

A majority of death penalty states treat prior history of violence as a factor in aggravation of murder which, if not outweighed by mitigating factors, permits a jury to impose the death penalty. Such factors as prior felony conviction, prior history of violence, and prior conviction for murder express the condemnation of a history of violence common in the capital statutes. Male murderers with prior convictions for a violent felony are substantially more likely to face trial than are female murderers with a comparable record. Twenty percent of male murderers but only 5 percent of female murderers convicted in state courts in 1986 had a prior conviction for a violent felony. ${ }^{11}$ Thus male murderers were four times more likely to possess a disadvantageous prior history that would induce a prosecutor to seek a capital trial and a jury to impose a death sentence.

An important measure of offense seriousness as interpreted by

10 Thirty-four of the thirty-seven death penalty states have enacted statutes that stipulate the factors in aggravation, which, in the absence of overbalancing factors in mitigation, permit sentencers to impose the death penalty. See Cornell Law Review 1984, which tallies the number of instances of each type of aggravating factor in the statutes of states that have the aggravating factor format. Since the publication of this catalog, Massachusetts has abandoned the death penalty and Vermont has adopted a statute of the same type; there have also been a number of statutory emendations. See Rapaport 1990 for a detailed analysis of the statutory categories and survey of developments since the Cornell Law Review article appeared. Texas, Utah, and Virginia have distinctive statutory schemes that narrow the class of murders eligible for death sentencing through other statutory devices. See Blumstein et al. (1983:69-125) for a review of the literature on determinants of sentences.

11 These results were arrived at by analyzing data collected by the U.S. Department of Justice, which surveyed felons convicted in state courts in 1986. Unlike in the discussion of FBI SHR data above, "murderer" is used here more strictly and hence excludes persons convicted of nonnegligent manslaughter. The data were obtained through the Inter-University Consortium for Political and Social Research. I would like to thank Dr. Bruce Burchett of the Duke University Center for the Study of Aging and Human Development for assistance in analyzing the survey tapes. For the published results of the Bureau of Justice Statistics survey of felons convicted in state courts in 1986, see U.S. Bureau of Justice Statistics 1990. 
modern death penalty statutes is the amount of violence or brutality employed by the offender. The statutes stigmatize excessive violence and attempt to measure it by asking juries to consider such factors as whether the murder was brutal, whether torture was employed, whether persons other than the victims were placed at grave risk, and whether more than one victim perished. Men are demonstrably more prone than women to commit violent crime: ${ }^{12}$ If men are also likely to employ more violence during the commission of murder than are women, then the gap between the expected representation of men and women on death row would again narrow. Notoriously, many of the measures of excessive violence employed by the statutes lend themselves to subjective variation in the responses of juries who are asked to determine whether a murder is markedly vile, heinous, or brutal. However, the only completely objective measure of brutality, the number of victims, is also especially salient in influencing sentencing outcomes. Although multiple homicides are quite rare, they are substantially more likely to lead to death sentences than are single victim killings. ${ }^{13}$ In the twelve-year period 1976-87, only 7.2 percent of multiple murder suspects were female, ${ }^{14}$ again suggesting that one should not expect female death sentences to approach the 14 percent mark reflecting female involvement in murder of every category.

Finally, there is the question of the relative culpability of male and female murderers. If female perpetrators of felony murders and other predatory murders are legitimately perceived as being less culpable than similar males, women would legitimately receive fewer death sentences than male murderers. For example, if women who figure in multiple perpetrator felony murders (most robbery murders are multiple perpetrator crimes; see Block 1985: 18) are commonly mere accomplices of men, one would expect a lower rate of death sentences for female robbery murderers. Relative culpability is much in need of further study, since it is an area in which at present we have little to guide us except unexamined stereotypical thinking. Common sense would incline many observers to suppose that women are often both perceived by prosecutors and juries to be, and objectively are, mere accomplices of dominant males. Others may be drawn to the equally stereotypical if perhaps more misogynist conjecture of Otto Pollak (1950), who speculated that women criminals control unsuspecting male colleagues through surreptitious manipulation, exposing the men to the brunt

12 According to FBI Uniform Crime Report (URC) data, e.g., in 1983 males accounted for 89 percent of arrestees for the violent crimes of homicide, rape, robbery, and assault. See U.S. Bureau of Justice, Statistics 1988:41.

13 See Gross and Mauro (1989:48-50), who found that killing more than one victim was one of the factors mostly likely to lead to a death sentence in their study of Florida, Georgia, and Illinois in 1976-80.

14 FBI SHR data. See note 5 supra. 
of the blame in the event of legal consequences. Not even tentative conclusions can be drawn about relative culpability without further study.

In sum, although there is ample scope for further study before fully satisfactory conclusions can be reached, the explanation for much, if not all, of the apparent disparity between the proportion of murderers who are women and the proportion of women on death row is not chivalrous regard for the female sex. It is to be found in the differences between the kinds of murders men and women commit and the kinds of personal history they present to prosecutors and sentencers: Female murderers are dramatically less likely than male murderers to have committed predatory murder and to appear in the dock as habitual and exceptionally violent felons. The sparseness of women on death row reflects our society's judgments about the nature of the most reprehensible and hence most severely sanctioned crimes rather than our protectiveness of women.

The soundness of our society's grading of homicide offenses is the subject of part III. In part II, I compare men and women who are selected for death row: Are the admissions criteria for death row the same for the men and women? How like or unlike are these men and women and the crimes they have committed?

\section{PROFIIES OF DEATH SENTENCED WOMEN AND MEN}

Death sentences are rare for both sexes. Only 2 percent of those convicted of murder or nonnegligent manslaughter are capitally sentenced (U.S. Bureau of Justice Statistics 1990:9), and thus far only 3 percent of those condemned in the modern era have actually been executed. ${ }^{15}$ Whether or not there is greater reluctance to death sentence women, a small stream of women have been death sentenced; each year has brought new female inmates to death row. The relative rareness of the capital sentencing of women creates both opportunities and impediments for the researcher. On the one hand, the small number of cases invites indepth study of female death row. On the other hand, the inquirer must canvass a relatively long span of years and large number of states in order to gather cases for study. The small number of cases also limits the confidence one can have that the data reflect meaningful shifts or stable levels.

To learn whether women and men come to death row by similar or different routes, I compared a set of male and a set of female death row inmates, all thirty-nine women death sentenced in a ten-year period 1978-87 and-all eighty-four males death sentenced

15 U.S. Bureau of Justice Statistics (1989:8). Almost 40 percent of those death sentenced in 1977-88 have left death row without suffering execution, a few because of death by other causes or commutation, the great majority as the result of appellate court action. 
in North Carolina June 1977-January $1989 .^{16}$ Because the postconviction review process is so lengthy and uncertain, and because so few death-sentenced persons have actually been executed in the modern era-and only one woman, North Carolina's Velma Barfield, has been among them, I have focused on death sentences rather than executions. ${ }^{17}$ The central question pursued is what leads a modern era jury to sentence a man or woman to die?

Table 3 presents a comparison of the contemporary male and female death row cases with respect to three factors identified in the first part of this article as likely to lead to the capital sentencing of convicted murderers-that the murder was committed in the course of another felony, that there was more than one victim, and that the killer had a prior conviction for a felony of violence. Although the men exceed the women in each of these indications, it is only with respect to prior felony convictions that the gap between the sexes is statistically significant.

These figures do not allow us to test directly whether the women defendants sentenced to death are selected from among women murder defendants according to the same criteria as are the males sentenced to death. It is possible, for example, that fewer of the women sentenced to death have a history of a prior violent felony because fewer women who murder have such a history.

On one important variable, however, we can compare the characteristics of men and women sentenced to death with the pattern among murder suspects. While the SHR figures (see Table 2) show that 22.1 percent of the murders committed by male suspects are against intimates, only 12 percent of the males sentenced to death in North Carolina had killed intimates; these figures suggest that murders of nonintimates by men are twice as likely to lead to the death penalty as are murders of intimates. In contrast, the percentage of intimacy murders among women on death row more equally represents the percentage of intimacy murders women committed; 65.5 percent of the female murder suspects killed intimates, and 49 percent of the women sentenced to death did so. The high percentage of intimacy murders among death-sentenced

16 Note that North Carolina gave more than than two times the number of death sentences to men during June 1977-January 1989 than the entire country gave to women in the ten years of 1978-89. In the typical study of sentencing discrimination, the researcher examines the probability of a particular outcome, e.g., death sentences for black versus white defendants. The difficulty confronting research on gender discrimination and the death penalty is that the number of death-sentenced women is miniscule for any jurisdiction and in fact tiny for the nation as a whole. As a result, $I$ have focused here on offenders selected for death in order to determine what characterizes the few women who are sent to death row:

17 Thus far, 53.9 percent of these women and 47.6 percent of the men have had.sentencing relief for numerous reasons spanning appellate rulings that their sentences were excessive to procedural grounds that did not address the appropriateness of a death sentence in their cases. 
Table 3. Women Death Sentenced 1978-1987 and North Carolina Men Death Sentenced 1977-1989 Whose Cases Included the Aggravating Factors of Felony Murder, Multiple Victims, or Prior Convictions for Violent Felonies

\begin{tabular}{lccc}
\hline & Women & Men & $\begin{array}{c}\text { Chi-Square } \\
\text { (1 df, Corr. Cont.) }\end{array}$ \\
\hline Felony murder & $38 \%$ & $55 \%$ & 2.21 \\
Prior conviction for violent felony & 3 & 32 & $6.46, p<.05$ \\
Multiple victims ${ }^{\mathrm{a}}$ & 18 & 24 & .19 \\
At least 1 of the 3 factors & 49 & 81 & $6.28,<.05$ \\
No. of offenders & 39 & 84 & \\
\hline
\end{tabular}

a Seven women were tried for more than one count of murder; juries heard evidence implicating women in multiple killing in an additional four cases, which in this table are treated as single-victim cases.

women may reflect differential treatment of male and female murders of intimates or differences in other attributes of the male and female offenders who commit murders. It may also reflect societal reaction to a particular kind of intimacy murder. Eleven of the nineteen women death sentenced for murder of an intimate in 1976-87 killed for pecuniary profit, a crime resembling paradigmatic stranger murder in motive. A full exploration of the relationship between gender, intimacy murder, and the death penalty must await further study when we have data on offender attributes and the prevalence of intimacy murder among nondeath-sentenced killers of both sexes.

\section{A GENDERED INTERPRETATION OF THE CONCEPTION OF OFFENSE SERIOUSNESS EMBEDDED IN CAPITAL PUNISHMENT LAW}

In a series of cases beginning in 1976, the Supreme Court has placed jurisdictions wishing to impose the death penalty under constitutional obligation (1) to guide and limit the discretion of sentencers in order to avoid the arbitrariness in death sentencing that infected the system in the past and (2) to abjure the death sentence altogether for crimes that our society no longer regards as sufficiently reprehensible to merit capital punishment. The Court has interpreted both mandatory death sentencing for a particular crime and death as a penalty for a crime that does not involve a fatality as violating contemporary U.S. perceptions of the limits of retributive justice. Most states that retain the death penalty, thirty-four out of thirty-seven, have responded to the requirement that discretion be guided by enacting statutes that enumerate the aggravating factors, which, if found to be present, and if not outweighed by mitigating factors, would permit the sentencing authority to impose the death penalty (see, e.g., Fla. Stat. Ann. $\S 921.141(5)$ (1989)). Analysis reveals that three broad categories of murders are stigmatized as death eligible in the death penalty statutes of this type: (1) predatory murder, (2) murder that hinders or 
threatens the enforcement of law or other governmental functions, and (3) murder that evinces excessive violence or brutality.

1. A predatory murder is one that is carried out for gain or advantage. The gain sought is usually, although not always, economic; ${ }^{18}$ it may be sexual, or it may involve some other form of domination of others; it may be revenge or the elimination of a rival. Under the felony murder rule, the full weight of the risk of a victim's death during certain predatory crimes, such as robbery and rape, is placed on the offender (see, e.g., Fla. Stat. Ann. $\$ 921.141(5)(d)(1989)$ ). The offender may be death sentenced even if he or she did not intend to kill the victim or if the victim is killed by a confederate. The apparent harshness of the felony murder rule reveals the depth of our distaste for predatory crime. Murdering for hire or hiring another to commit murder are also common predatory murder factors found in the statutes (see, e.g., Ariz. Rev. Stat. Ann. § 13-703(F)(4) (1989)).

2. Stigmatizing the murders of police officers, fire fighters, or correction officials are the most common of the ways in which the statutes protect the state's authority. ${ }^{19}$ Most death penalty statutes also make killing to prevent arrest or to escape custody and killing while incarcerated aggravating factors. Killing a judge, prosecuting attorney, or witness is a common aggravating factor while a few states make killing any governmental official a potentially capital matter (see, e.g., Cal. Penal Code $\$ 190.2(a)(11)-(13)(1990)$ ).

3. Excessive violence is condemned in the great majority of statutes; to kill cruelly (see, e.g., La. Code Crim. Proc. Ann. art. 905.4(A)(7) (1989)), to kill more than one victim (see, e.g., Ky. Rev. Stat. Ann. $\$ 532.025(2)(a)(6)(1989)$ ), to endanger others in addition to taking the life of a victim (see, e.g., Ga. Code $\$ 17-10-30(\mathrm{~b})(3)$ (1982)), to have killed before (Colo. Rev. Stat. $\S 16-11-103(6)$ (a) (1986)) or resorted to violence before are all forms of excess condemned by the statutes. A number of statutes mark the use of torture, explosives, or poison as rendering a murder susceptible to a capital sentence in addition to the blanket factor of cruelty or brutality. A prior history of violence or a prior felony conviction (see, e.g., Fla. Stat. Ann. \$ 921.141(5)(b) (1989)) or a prior murder conviction (see, e.g., Ga. Code $\$ 17-10-30(b)(1)$ (1982)) are commonly among the enumerated factors, as is creating a grave risk to more than one person (see, e.g., Fla. Stat. Ann. $\$ 921.141(5)(c)(1989)$ ).

If we examine the results of this analysis of the statutes with the eye of a feminist critic, we will note that special protection is not given to domestic life or relationships. The worst cases of domestic violence, unlike the worst cases of robbery violence, are not, as such, eligible for capital adjudication. Domestic crimes may

18 Thirty-three of the thirty-four state statutes that enumerate aggravating factors include murder for pecuniary gain among the factors.

19 The majority of statutes of this type have this provision. See; e.g., Ga. Code $\$ 17-10-30(b)(8)(1962)$. 
nonetheless become capital cases if they are regarded as especially brutal crimes or if they are also pecuniary crimes. But the paradigmatic domestic killing, arising out of hot anger at someone who is capable, as it were by definition, of calling out painful and sudden emotion in his or her killer, is virtually the antithesis of a capital murder. Yet there are features of domestic homicides that could plausibly be regarded as among the most reprehensible crimes: They involve the betrayal of familial trust and responsibility on which not only domestic peace but presumably our civilization depends, as much it depends on honoring the law of mine and thine and respecting the authority of the state. They also have characteristics that could be read as inherent extreme brutality. The victims of family murders are typically especially vulnerable to their killers because of physical weakness and psychological dependency. Often the victims have been the objects of prior and habitual violence by their killers.

Whether or not one endorses or opposes capital punishment on moral or other grounds, and whether or not one would wish to see its domain enlarged for any purpose, there is, from a feminist point of view, an invidious subordination of the interests of women involved in the failure of the statutes to attach our society's most profound condemnation to crimes that destroy the domestic peace. These murders are also far more likely to have women and children as victims than are economic crimes. Our law reveals a disposition to regard killing a stranger for gain as more heinous than killing a spouse or child in anger. This hierarchy of opprobrium both privileges the interests of men over those of women and children and supports patriarchal values. In what follows I first elaborate a feminist critique of the hierarchy of opprobrium in the statutes. I then argue that including the worst domestic murders among the most severely stigmatized crimes, despite the apparent counterintuitiveness of such a proposal, is consistent with the doctrinal structure of our law of homicide and the policies that may be inferred to underlie it.

The kinds of crimes that are most likely to result in death sentences-felony murders and other predatory murders-are most likely to be committed by men against other men and against women and children in other men's families. Of stranger murders, 96 percent are committed by males; 80 percent of the victims in stranger murders are also male (see FBI SHR data). Women are much more likely to be victimized by family-especially current and former spouses and lovers-than are men. In 1988, 31 percent of female victims but only 5 percent of male victims were accounted for in this fashion (Federal Bureau of Investigation 1989:13). Children, especially young children, are even more likely to be murdered at home. Child abuse fatalities have been estimated to exceed 1,000 per year (for estimates for 1986, 1987, and 1988, see Daro and Mitchel 1989). 
Although women are more likely to be victimized by intimates than men, they are also more likely to have intimates for victims. Indeed it is only in the domain of family murder that women kill nearly as many victims as do men. Nonetheless, it is in the interests of women that society treat domestic murder in its most aggravated forms as among the most heinous crimes.

Creating parity of opprobrium for the worst cases of domestic homicide-let us say by elevating serious and habitual abuse of a spouse or child to the status of a felony and including this felony among the enumerated felonies rendering a homicide eligible for capital sentencing-challenges directly the proposition that violence in the home, from which women and children suffer disproportionately, is less reprehensible than violence directed at a luckless clerk on night duty at a convenience store. ${ }^{20}$ The supposition that predatory violence is more reprehensible than domestic violence is a symptom or effect of the ancient family privacy doctrine that has supported male domestic authority, and the parental authority of both sexes, at the price of tolerating if not encouraging a culture of domestic violence.

Despite women's high rates of domestic murder, male efforts to maintain their domination in the domestic sphere may be the most fundamental cause of the majority of spousal homicides, regardless of the sex of the perpetrator. In the majority of cases when wives kill husbands, they have been provoked by the violence of husbands (see Wolfgang's classic 1958 analysis). Husbands, on the other hand, are most likely to kill wives not because they themselves are under physical attack but out of retaliation for what they perceive to be desertion or infidelity (Barnard et al. 1982). Recent studies have also uncovered a facet of fatal child abuse murder that also underscores the breadth and causative nature of the male role in domestic violence. The presence of a man in the home has been identified as a major risk factor for a fatal outcome to child abuse. Men, often boyfriends of the mother rather than men with a legal or biological relationship to the child victim, are involved in the majority of fatality cases (Alfaro 1988).

One piece of evidence that on the surface suggests social valuing of female victims is the finding that murderers of women are more likely to be death sentenced than murderers of men (Gross and Mauro 1989:50). We cannot, however, infer from this finding that the higher likelihood of a death sentence reflects a societal

20 Although no statute offers its protection to victims of spousal murder, two states (Mississippi and Utah) have recently amended their statutes to include felony child abuse among the felony circumstances that render a homicide eligible for capital sentencing. Five states (Arizona, Illinois; Louisiana, South Carolina, and Tennessee) treat the murder of a child as an aggravating factor. Delaware treats murder of any defenseless person as a factor in aggravation. Seven states, including both capital punishment and noncapital punishment states, have elevated child abuse homicide to first-degree murder. See Repella (1989:2). 
judgment that murders of female victims are in all circumstances more serious than murders of male victims. The greater likelihood that a female victim's killer will be death sentenced reflects, at least, the opprobrium with which we regard rape murder. Even if it proves to be the case that felony murderers of other types who kill female victims are at greater risk of a death sentence than those who kill males, we can conclude nothing from such a finding about the propensity of domestic killers of females to be death sentenced. The claim I am making here is that the capital statutes do not single out domestic killing as especially reprehensible; indeed, they single out crimes generally thought of as virtually opposite or complementary in type for that designation. If, however, it should prove to be the case that all predatory stranger killing of females, not merely rape murder, puts murderers at greater risk of a death sentence, the result would be compatible with the feminist analysis advanced here: It is congruent with patriarchal values, and offensive to feminist values, that violence against women belonging to others be more heavily sanctioned than violence against your own women.

At least three counterarguments are likely to be leveled at the feminist critique of the exclusion of the worst domestic homicides from among the most severely punished crimes. A consideration of their merits reveals the essentially ideological origin of the current moral grading of homicide offenses.

1. The most plausible defense for the relative leniency of our response to domestic murder takes the following form: It is a generalization of Wolfgang's (1958) theory of victim-precipitated homicide. If acquaintances, friends, and most especially family members quarrel and a homicide ensues, we are disposed to view the victim . as sharing some responsibility with his or her killer for the killing-whether or not the provocation would be considered legally sufficient to reduce the charge from murder to manslaughter. The victim is regarded as having assumed a measure of the risk of victimization simply by remaining in an intimate relationship with the killer whom he or she may have known to be disposed to violence. We assume that the victim possessed some degree of control over the circumstances of his or her victimization, which puts the homicide in a less frightening light and diminishes the degree of punishment that appears appropriate.

There is a fatal objection to this theory: It is unable to account for the lesser opprobrium ascribed to the killing of a young child. Nor can it account for the relative leniency of response to the murder of an adult who is psychologically or otherwise dependent on his or her killer, as may be the case with a battered spouse.

2. The feminist critique of capital statutes offered here could also be accused of failing to respect the theory of relative culpability inherent in our law of homicide. Our law of homicide regards the unprovoked and calculated killer, the cold-blooded killer, as 
more reprehensible than the hot-blooded killer. Therefore, it may be said; because family murders are paradigms of hot-blooded crime, they ought not to be dealt with as harshly as cold-blooded, predatory murder. However, it must be noted that ever since the introduction of degrees of murder, first-degree murder has included, in addition to deliberate and premeditated murder, felony murder. Conviction for felony murder does not require that the offender killed intentionally, much less with deliberation and premeditation. Felony murderers are not held capitally responsible for their actions because their crimes were cold-blooded in the sense that they were deliberate or premeditated. Our society places the full measure of the risk of a victim's death on the one who would use violence for a predatory end. Similarly, if we chose to do so, our traditional law of homicide offers no conceptual barrier to treating child abuse or spouse abuse as a felony capable of sustaining a capital sentence if a fatality results from it. To do so would be to make the moral and ideological choice to place the risk of a victim's death on someone using violence in the interests of domestic tyranny.

3. The feminist critic could also be taxed for failing to appreciate that cold-blooded killings are more apt to be subjected to the death penalty because cold-blooded killing is more susceptible to deterrence through severity of sanction than hot-blooded crime. I will not comment here on the vexing and contested question of whether the death penalty does in fact possess deterrent value. Suffice it to say that other kinds of murder now deemed capital are not obviously more or less susceptible to deterrence through severity of sanction than murder in the course of felonious domestic violence. Killing in the course of an armed robbery or killing a peace officer to avoid arrest are capital crimes that may not be either planned or coolly executed; they may be the product of panic, confusion, or lack of self-control. If such potential offenders are deterrable, deterrence presumably often takes the form of dissuading them from predatory crime rather than self-mastery in the midst of commission of felonies. By parity of reasoning, if we choose to, we could similarly attempt to deter severe family abuse by putting potential abusers on notice that society regards killing in the course of aggravated and habitual domestic abuse as among the most reprehensible forms of killing.

My purpose in offering a feminist critique of our capital punishment system is not in fact to advocate capital punishment for domestic murder. Nor would I wish to endorse the view that criminal law is the best, or the only, or an adequate, tool for dealing with all facets of the problem of domestic violence. My purpose rather is to expose the ideological biases of the status quo in which domestic homicide is treated, invidiously, as .almost always less reprehensible than predatory murder. The logic of the argument suggests that egregious cases of domestic murder should be among 
the most severely condemned crimes and therefore eligible for the heaviest sanctions, whatever these may be. Such an allocation of penalties would use the law of homicide in the inculcation of new social values and the concomitant guiding of conduct.

It may well be that the underevaluation of the heinousness of domestic murder is the most serious form of gender discrimination to be discovered in our capital punishment system. In the present state of our knowledge, I have tried to show, we have no credible evidence that women are spared the death penalty in circumstances where it would be pronounced on men. The gender composition of death row rather appears to reflect differences between the kinds of homicides men and women commit. Additionally, there is some evidence that the admissions standards for death row may be somewhat different for the two sexes. Although women are indeed sent to death row for crimes that lead men to the same fate, a strikingly high percentage of the women on death row, unlike the men, killed family or intimates. The question of the death penalty and gender discrimination, then, appears to be fundamentally a question of social ideology. Women are doubly disserved by the current climate of belief and policy. First, women are disserved by the misleading or false belief that we are spared the most extreme criminal sanction because of our sex. Second, the criminal law is not being mobilized to sufficiently discredit, discourage, and sanction crimes of domestic oppression from which women and children suffer disproportionately.

\section{REFERENCES}

ALFARO, Jose (1988) "Studying Child Maltreatment Fatalities: A Synthesis of Nine Projects," in D. Besharov (ed.), Protecting Children from Abuse and Neglect: Policy and Practice. Springfield, IL: Charles C. Thomas.

BEDAU, Hugo A. (ed.) (1982) The Death Penalty in America. 3d ed. New York: Oxford University Press.

BALDUS, David, Charles A. PULASKI, and George WOODWORTH (1986) "Arbitrariness and Discrimination in the Administration of the Death Penalty: A Challenge to State Supreme Courts," 15 Stetson Law Review 133.

BALDUS, David, George WOODWORTH, and Charles PULASKI, Jr. (1985) "Monitoring and Evaluating Contemporary Death Sentencing Systems: Lessons from Georgia," 18 University of California Davis Law Review 1375. (1990) Equal Justice and the Death Penalty. Boston: Northeastem University Press.

BARNARD, George, Hernan VERA, Maria VERA, and Gustave NEWMAN (1982) "Till Death Do Us Part: A Study of Spouse Murder," 10 Bulletin of the American Academy of Psychiatry and Law 271.

BLOCK, Carolyn (1985) "Lethal Violence in Chicago over Seventeen Years: Homicides Known to the Police 1965-81." Chicago: Illinois Criminal Justice Information Authority.

BLUMSTEIN, A., J. COHEN, S. MARTIN, and M. TONRY (eds.) (1983) "Determinants of Sentences," 1 Research on Sentencing: The Search for Reform. Washington, DC: National Academy Press.

CORNELL LAW REVIEW (1984) "Capital Punishment in 1984: Abandoning the Pursuit of Fairness and Consistency," 69 Cormell Law Review 1129. 
DARO, Deborah, and Leslie MITCHEL (1989) "Child Abuse Fatalities Continue to Rise: The Results of the 1988 Annual Fifty State Survey." Report prepared for the National Center of Child Abuse Prevention-Research, Washington, DC.

EKLAND-OLSON, Sheldon (1988) "Structured Discretion, Racial Bias and the Death Penalty," 69 Social Science Quarterly 853.

FEDERAL BUREAU OF INVESTIGATION (1989) Uniform Crime Reports. Federal Bureau of Investigation. Washington, DC: Government Printing Office.

GILLESPIE, Cynthia (1989) Justifiable Homicide. Columbus: Ohio State University Press.

GROSS, Samuel, and Robert MAURO (1989) Death and Discrimination. Boston: Northeastern University Press.

LITTLETON, Christine A. (1987) "Restructuring Sexual Equality," 75 California Law Review 1279.

MINOW, Martha (1987) "Foreword: Justice Engendered" 101 Harvard Law Review 10.

NAACP LEGAL DEFENSE AND EDUCATIONAL FUND (1991) Death Row U.S.A. (January).

NAKELL, Barry, and Kenneth HARDY (1987) The Arbitrariness of the Death Penalty. Philadelphia: Temple University Press.

POLLAK, Otto (1950) The Criminality of Women. Philadelpha: University of Pennsylvania Press.

RAPAPORT, Elizabeth (1990) "Some Questions About Gender and the Death Penalty," 20 Golden Gate University Law Review 501.

REPELLA, J. (1989) "Prosecution of Child Abuse Deaths-Statutory Framework." Alexandria, VA: National Center for the Prosecution of Child Abuse.

SELLIN, Thorsten (1980) The Penalty of Death. Beverly Hills, CA: Sage Publications.

STRIEB, Victor (1990) "The Death Penalty for Female Offenders," 58 Cincinnati Law Review 845.

ـــ (1991) "Capital Punishment for Female Offenders: Present Female Death Row Inmates and Death Sentences and Executions of Female Offenders, January 1, 1973, to March 1, 1991." Unpublished, Cleveland-Marshall College of Law, Cleveland, Ohio.

U.S. BUREAU OF JUSTICE STATISTICS (1988) Report to the Nation on Crime and Justice. 2d ed. Washington, DC: Government Printing Office. (1989) Capital Punishment 1988. Washington; DC: Government Printing Office.

- (1990) "Profile of Felons Convicted in State Courts, 1986." Washington, DC: Government Printing Office.

WILLIAMS, Wendy (1982) "The Equality Crisis: Some Reflections on Culture, Courts, and Feminism," 7 Women's Rights Law Reporter 175.

WOLFGANG, Marvin (1958) Patterns in .Criminal Homicide. New York: John Wiley.

\section{CASES CITED}

Furman v. Georgia, 408 U.S. 238 (1972).

\section{STATUTES CITED}

Ariz. Rev. Stat. Ann. \& 13-703(F)(4) (Supp. 1989).

Cal. Penal Code $\S 190.2(a)(11)$-(13) (West Supp. 1990).

Colo. Rev. Stat. § 16-11-103(6)(a) (Supp. 1986).

Fla. Stat. Ann. § 921.141(5)(b)-(d) (West Supp. 1989).

Ga Code Ann. \& 17-10-30(b)(1), (3), (8) (1982).

Ky. Rev. Stat. Ann. § 532.025(2)(a)(6) (Baldwin 1989).

La. Code Crim. Proc. Ann. art. 905.4(A)(7) (West Supp. 1989). 